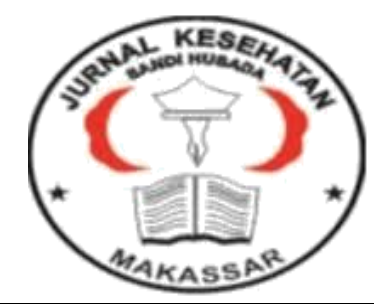

\author{
Jurnal Ilmiah Kesehatan Sandi Husada \\ hhttps://akper-sandikarsa.e-journal.id/JIKSH \\ Volume 9, Nomor 2, Desember 2020, pp 1009-1016 \\ p-ISSN: 2354-6093 dan e-ISSN: 2654-4563 \\ DOI: $10.35816 /$ jiskh.v10i2.454
}

\title{
Komplikasi Muskuloskeletal pada Pasien Diabetes Melitus
}

Musculoskeletal Complications in Diabetes Mellitus Patients

\section{Dirga Yudha Prakasa}

Program Studi Pendidikan Dokter, Fakultas Kedokteran Universitas Lampung

\section{Artikel info}

\section{Artikel history:}

Received; Agustus 2020

Revised: September 2020

Accepted; Oktober 2020

\section{Abstract.}

Background. Apart from macrovascular and microvascular complications, diabetic patients may experience some musculoskeletal complications. The impact of musculoskeletal complications on the quality of life of diabetics is enormous. There are many epidemiological data linking this complication to diabetes, but the pathogenesis and causative factors have not been elucidated. Therefore, the aim of this literature study is to further investigate musculoskeletal complications in diabetes mellitus patients. Method. This study is a literature review, with 18 literature sources, from 1 national journal and 17 international journals. Result. Several studies have shown that musculoskeletal complications that are often found in people with diabetes mellitus include shoulder capsulitis, limited joint mobility syndrome, Dupuytren's contracture, carpal tunnel syndrome and trigger finger. Vascular and nerve damage, protein glycosylation, and increased collagen in the skin and musculoskeletal connective tissue are some of the factors thought to contribute to the development of musculoskeletal disorders in diabetics. Conclusion. The musculoskeletal manifestations of diabetes are common, and although they are not life threatening, they are an important cause of morbidity, pain and disability.

\footnotetext{
Abstrak

Latar belakang. Selain komplikasi makrovaskular dan mikrovaskuler, pasien diabetes mungkin mengalami beberapa komplikasi muskuloskeletal. Dampak komplikasi muskuloskeletal terhadap kualitas hidup penderita diabetes sangat besar. Terdapat banyak data epidemiologi yang mengaitkan komplikasi ini dengan diabetes, tetapi patogenesis dan faktor penyebab belum dijelaskan lebih lanjut. Oleh karena itu, tujuan dari studi literatur ini adalah untuk mengetahui lebih lanjut komplikasi muskuloskeletal pada pasien diabetes melitus. Metode. Studi ini merupakan literature review, dengan sumber pustaka yang digunakan sebanyak 22 pustaka, berasal dari 1 jurnal nasional dan 21 jurnal internasional. Hasil. Beberapa penelitian menunjukkan komplikasi muskuloskeletal yang sering dijumpai pada penderita diabetes melitus antara lain kapsulitis bahu, sindrom mobilitas sendi terbatas (LJM), kontraktur Dupuytren, carpal tunnel syndrome dan trigger finger. Kerusakan pembuluh dan saraf, glikosilasi protein, dan peningkatan kolagen di kulit dan jaringan ikat muskuloskeletal
} 
adalah beberapa faktor yang diduga berkontribusi dalam perkembangan gangguan muskuloskeletal pada penderita diabetes. Kesimpulan. Manifestasi muskuloskeletal dari diabetes sering ditemui, dan meskipun tidak mengancam nyawa, ia merupakan penyebab penting dari morbiditas, nyeri dan kecacatan.

Keywords:

diabetes mellitus,

complications,

musculoskeletal.
Coresponden author:

Email: dirgayudhaa@gmail.com

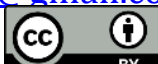

artikel dengan akses terbuka dibawah lisensi CC BY -4.0

\section{Pendahuluan}

Gangguan endokrin adalah kelompok kelainan heterogen yang menyebabkan gangguan hormonal. Hormon adalah bagian penting dari homeostasis dalam tubuh. Dengan demikian, disregulasi hormonal mempengaruhi hampir setiap sistem tubuh, termasuk sistem kardiovaskular, paru, gastrointestinal, genitourinari, dermatologis, neurologis, dan muskuloskeletal (Boswell et al., 2014). Diabetes mellitus adalah salah satu gangguan metabolisme yang paling umum terjadi di negara berkembang dan maju. (Kiani et al., 2014). Diabetes mellitus (DM) ditandai dengan peningkatan kadar glukosa plasma, akibat dari tidak adanya atau sedikit sekresi insulin dengan atau tanpa gangguan bersamaan dari kerja insulin (Arsanjani Shirazi et al., 2016).

Penyakit ini dianggap sebagai salah satu masalah utama dalam sistem kesehatan, dan ancaman kesehatan masyarakat global, yang prevalensinya telah meningkat secara dramatis selama 2 dekade terakhir. Perkiraan terbaru dari International Diabetes Federation (IDF), menunjukkan tingkat prevalensi global diabetes sebesar 8,4\% pada orang dewasa, dan sebanyak 382 juta kasus diabetes pada 2013. Berdasarkan kecenderungan saat ini, diperkirakan angka ini akan berlipat ganda pada tahun 2050 (Boyle et al., 2010; Arsanjani Shirazi et al., 2016). Sekitar 90\% pasien diabetes merupakan DM tipe 2, yang ditandai dengan berbagai tingkat resistensi dan defisiensi insulin. Sedangkan DM tipe 1 adalah kondisi autoimun, yang ditandai dengan penghancuran sel beta penghasil insulin, yang mengakibatkan kekurangan insulin seumur hidup. Di negara maju, DM tipe 1 meningkat dengan kecepatan sekitar 4\% setahun (Lehuen \& Ph, 2015; Merashli et al., 2015). Sementara itu, DM tipe 2 merupakan ancaman yang serius bagi dunia khusunya negara berkembang seperti Indonesia, dimana hampir $80 \%$ dari kejadian DM tipe 2 terjadi pada negara-negara berkembang yang berpenghasilan menengah kebawah (Saputri, 2020).

Meskipun diabetes secara luas dikenal sebagai penyebab morbiditas dan mortalitas yang signifikan akibat infark miokard, stroke, gagal ginjal, gangguan penglihatan, dan ulserasi kaki, belum diketahui secara luas bahwa diabetes dikaitkan dengan sejumlah kondisi muskuloskeletal. Pasien dengan diabetes dapat mengalami beberapa sindrom atau gejala muskuloskeletal, banyak di antaranya terkait dengan keparahan dan durasi penyakit. Kondisi ini dapat mempengaruhi persendian, jaringan lunak, saraf, otot atau tendon. Beberapa dari kondisi ini berasal dari komplikasi diabetes lainnya, seperti neuropati perifer, dan juga secara langsung disebabkan oleh kelainan metabolik, dengan glikosilasi langsung yang merusak jaringan. Meskipun komplikasi muskuloskeletal diabetes jarang mengancam nyawa, komplikasi ini biasanya terjadi pada pasien yang memiliki komplikasi lain seperti kondisi kardiovaskular, neuropatik, nefropati, atau retinal, dan dapat menyebabkan kecacatan yang signifikan (Merashli et al., 2015). Sehingga, komplikasi muskuloskeletal terhadap kualitas hidup penderita diabetes memiliki dampak yang sangat besar. Komplikasi muskuloskeletal diabetes sebagian besar dapat dikategorikan menjadi dua kategori, yaitu pengaruh diabetes pada jaringan otot, dan pengaruh diabetes pada 
jaringan sendi dan ikat (Singla et al., 2015). Oleh karena itu, tujuan dari literature review ini adalah untuk meninjau beberapa manifestasi muskuloskeletal diabetes yang ditemukan, sehingga dapat memberikan informasi yang bermanfaat bagi masyarakat luas.

\section{Metode}

Metode yang digunakan adalah studi literatur yang diambil dari beberapa jurnal nasional maupun internasional dan artikel ahli yang diakses online. Metode ini berupaya meringkas pemahaman kondisi terkini mengenai suatu topik. Studi literatur ini menyajikan materi yang telah diterbitkan sebelumnya dan menganalisis suatu fakta baru Penelusuran sumber pustaka dalam artikel ini melalui database PubMed dan Google Scholar. Sumber pustaka yang digunakan dalam penyusunan melibatkan 22 sumber pustaka yang terdiri dari 1 jurnal nasional dan 21 jurnal internasional. Pemilihan artikel sumber pustaka dilakukan dengan melakukan peninjauan pada judul, abstrak dan hasil yang membahas komplikasi muskuloskeletal pada pasien diabetes melitus.

\section{Hasil Dan Pembahasan}

Penelitian oleh Ramchurn et al (2009), pada 96 pasien diabetes dan 100 orang non diabetes pada kelompok kontrol, didapatkan bahwa penyakit muskuloskeletal ditemukan pada $75 \%$ penderita diabetes dengan ekstremitas atas merupakan tempat yang paling umum untuk kelainan. Prevalensi ini secara signifikan lebih tinggi daripada yang terlihat pada kontrol (53\%) dengan nilai $p=0,02$. Kapsulitis bahu (25\%), carpal tunnel syndrome (20\%), tenosynovitis (29\%), mobilitas sendi terbatas (28\%) dan kontraktur Dupuytrens (13\%) adalah temuan yang paling sering ditemukan dan lebih umum daripada di kontrol. Kapsulitis biasanya berdampingan dengan kelainan ekstremitas atas lainnya dan paling baik memprediksi adanya retinopati dan atau neuropati. Rata-rata HbA1c secara signifikan lebih tinggi pada pasien dengan kombinasi masalah bahu dan tangan $(9,1 \%)$ dibandingkan pada mereka yang tidak memiliki masalah ekstremitas atas $(8,0 \%)$ dengan nilai $p=0,018$. Pola hasil ditemukan serupa pada DM tipe 1 dan tipe 2, meskipun prevalensi kelainan dan rata-rata Health Assesment Questionnaire (HAQ) secara signifikan lebih besar pada pasien DM tipe 2, (Ramchurn et al., 2009)

Hasil penelitian tersebut juga sejalan dengan penelitian oleh mustafa (2016), pada 1000 pasien dengan DM tipe 2 dengan usia rata-rata 57,8 \pm 9,5 tahun, yang terbagi menjadi $52,2 \%$ perempuan dan $47,8 \%$ laki-laki. Gangguan pada tangan (hand disorder) terlihat pada $69,5 \%$ pasien, mobilitas sendi terbatas (limited joint mobility/ LJM) adalah kondisi yang paling umum $(63,1 \%)$, diikuti oleh kontraktur Dupuytren (18,6\%). Triggerfinger, thick skin dan carpal tunnel syndrome ditemukan masing-masing pada 7,2\%, 6,2\% dan $5,5 \%$ pasien. Penemuan satu jenis gangguan terlihat pada $45,4 \%$ pasien, dua jenis gangguan dalam $18,2 \%$ pasien, tiga jenis gangguan pada $4,9 \%$ pasien, empat jenis gangguan pada $0,9 \%$, sementara hanya $0,1 \%$ pasien yang mengalami semua gangguan. Jenis kelamin perempuan, usia di atas 60 tahun dan durasi diabetes yang lama dikaitkan dengan hand disorder. Hipertensi secara signifikan dikaitkan dengan kontraktur Dupuytren, sementara retinopati dikaitkan dengan peningkatan kemungkinan thick skin, kontraktur Dupuytren dan carpal tunnel syndrome dengan nilai $p$ masing-masing 0,037, $<0,005$ dan 0,002 (Mustafa et al., 2016).

Sementara itu, Yang et al (2019) menunjukkan, jumlah rata-rata gejala muskuloskeletal secara signifikan lebih tinggi pada wanita dengan DM tipe 2 dibandingkan wanita tanpa 
DM tipe 2, dengan penilaian skor keparahan rata-rata. Rerata \pm SD jumlah gejala muskuloskeletal dari total peserta adalah 2,68 $\pm 2,41$ (kisaran, 0-9), sedangkan rerata \pm SD skor keparahan untuk gejala muskuloskeletal adalah 8,37 $\pm 8,74$ (kisaran, 0 -36). Rerata \pm SD jumlah gejala, secara signifikan lebih tinggi pada wanita dengan DM tipe 2 sebesar 3,69 $\pm 2,57$, dibandingkan pada mereka yang tidak memiliki DM tipe 2 sebesar 2,07 $\pm 2,09$ dengan nilai $p<0,001$. Begitu pula rerata \pm SD skor keparahan pada wanita dengan DM tipe 2 sebesar 12,19 \pm 9,98 dan tanpa DM tipe 2 sebesar 6,04 $\pm 6,98$ dengan nilai $p<0,001$ (Yang et al., 2019).

Kerusakan pembuluh dan saraf, glikosilasi protein, dan peningkatan kolagen di kulit dan jaringan ikat muskuloskeletal adalah beberapa faktor yang diduga berkontribusi dalam perkembangan gangguan muskuloskeletal pada penderita diabetes (Kiani et al., 2014). Konsentrasi glukosa darah tinggi secara langsung bertanggung jawab atas peningkatan ikatan silang kolagen melalui produk akhir glikosilasi, yang menurunkan kelarutan dan daya cerna kolagen. Hal ini pada akhirnya meningkatkan kekakuan baik kolagen maupun struktur yang dibangun di atas kolagen kerangka (misalnya tendon), sehingga membuatnya lebih rentan terhadap kontraktur (Uhl et al., 2014). Terdapat juga hubungan yang jelas antara disfungsi metabolik yang ditemukan pada DM tipe 2 dan patologi muskuloskeletal. DM tipe 2 mempercepat perkembangan dan keparahan osteoartritis (Mooney et al., 2011; Schett et al., 2013), dan juga meningkatkan risiko patah tulang (Moseley, 2012). Selain efeknya pada kartilago dan tulang, DMT2 juga merusak homeostasis tendon dan perbaikan setelah cedera akut (Nichols et al., 2020). Dalam teori lain, dikatakan bahwa neuropati motorik akibat perubahan keseimbangan mekanis antara otot ekstrinsik dan intrinsik kaki dapat menyebabkan deformitas muskuloskeletal. Selain itu, neuropati sensorik membuat pasien tidak menyadari perubahan tulang dan menyebabkan kerusakan progresif tulang dan sendi (Varma, 2013; Arsanjani Shirazi et al., 2016). Kapsulitis bahu, mobilitas sendi terbatas (LJM), kontraktur Dupuytren, carpal tunnel syndrome, dan trigger finger adalah gangguan muskuloskeletal yang paling umum pada ekstremitas atas yang menyebabkan nyeri, ketidaknyamanan, gerakan terbatas, dan kualitas hidup yang buruk pada pasien diabetes (Kiani et al., 2014).

Pada DM, gangguan pada bahu digambarkan sebagai manifestasi muskuloskeletal yang paling menyulitkan. Kapsulitis bahu (juga dikenal sebagai frozen shoulder) muncul sebagai limitasi yang hampir lengkap pada mobilitas pasif dan aktif bahu, terutama pada adduksi dan rotasi eksternal. Kondisi itu terjadi secara progresif dan menyakitkan, menyebabkan kontraktur kapsul sendi, yang melekat pada kaput humerus, mengurangi volume sendi. Pemeriksaan histologis kapsul menunjukkan proliferasi fibroblas dan transformasinya menjadi mioforblas, yang menghasilkan kolagen tipe 1 dan tipe 3 dalam jumlah berlebihan. Temuan tersebut serupa dengan temuan pada DC. Nyeri muncul pada malam hari pada awalnya dan terjadi secara bertahap yang dapat dibagi menjadi tiga fase yaitu fase nyeri, kekakuan dan pemulihan. Beberapa penelitian, telah melaporkan prevalensi kapsulitis bahu yang lebih tinggi dari infark miokard pada mereka dengan DM tipe 1, dan neuropati otonom pada mereka dengan DM tipe 1 dan 2. Terapi kapsulitis bahu terdiri dari analgesik, infiltrasi kortikosteroid, dan fisioterapi. Kebanyakan pasien dapat memulihkan fungsi normalnya. Pada fase adhesif, 'kapsul' dapat dilepas melalui manipulasi dengan anestesi atau pembedahan. Pembedahan lebih disukai dilakukan melalui artroskopi daripada pembedahan terbuka, karena dapat mengurangi masa pemulihan pasca pembedahan (Silva \& Skare, 2012).

Sindrom mobilitas sendi terbatas (LJMS) adalah keterbatasan mobilitas tangan, kaki, dan sendi besar yang tidak menimbulkan nyeri. Kelainan biokimia berikut tampaknya terkait dengan munculnya LJMS: peningkatan glikosilasi non-enzimatik serat kolagen; 
peningkatan ikatan silang kolagen dan akibatnya resistensi terhadap pencernaan enzimatik; peningkatan hidrasi yang dimediasi oleh jalur reduktase aldolase; dan peningkatan pembentukan produk akhir glikosilasi lanjutan (advanced glycosylation end product/ AGEs). LJMS diyakini dipengaruhi oleh kontrol glikemik yang buruk, meskipun hubungan antara komplikasi muskuloskeletal dan kontrol glikemik, atau bahkan kadar HbA1C, masih kontroversial. Namun, perlu dicatat bahwa kadar glikemia dan HbA1C tidak mencerminkan periode hiperglikemia yang lalu, yang mungkin telah ada bertahun-tahun sebelum diagnosis DM tipe 2. Pengobatan yang dianjurkan adalah terapi fisik dan anti inflamasi nonsteroid (NSAID). Namun, sebelum meresepkan obat tersebut, perlu diperhatikan kaitan sindrom tersebut dengan nefropati diabetik, untuk menghindari efek samping yang tidak diinginkan. Dengan adanya keterlibatan kulit, satu-satunya pengobatan yang diusulkan adalah kontrol glikemik. (Silva \& Skare, 2012).

Kontraktur Dupuytren (DC) ditandai dengan penebalan, pemendekan, dan fibrosis dari fasia palmar. Proses ini menghasilkan kontraktur fleksi pada jari yang terkena, yang biasanya tidak menimbulkan rasa sakit. Pemeriksaan pada tangan juga menunjukkan adanya nodul palmar yang teraba. Pada subjek nondiabetes, jari keempat dan kelima biasanya terkena, tetapi pada subjek dengan diabetes, DC terutama mempengaruhi jari ketiga dan keempat. Etiologi DC dianggap mirip dengan LJM dan kecenderungan genetik dianggap mendasari frekuensi yang lebih tinggi pada beberapa populasi (orang Celtic, Skandinavia, dan keturunan Skotlandia lebih tinggi dibandingkan dengan keturunan Eropa Timur, Afro Amerika, Asia, atau Timur Tengah). Hiperglikemia dan mikroangiopati jangka panjang diketahui juga merupakan kontributor penting. Secara khusus, penyakit mikrovaskuler diyakini menyebabkan produksi radikal bebas oksigen yang dimediasi hipoksia, yang kemudian menyebabkan proliferasi fibroblast dan sekresi growth factor dan sitokin yang berlebihan, yang mengakibatkan produksi kolagen lokal berlebih dan fibrosis (Papanas \& Maltezos, 2010). Gangguan ini mempengaruhi sekitar 16-32\% pasien, lebih umum di antara lansia dan mereka dengan durasi DM lebih lama. Kontraktur Dupuytren dapat diobati dengan infiltrasi kortikosteroid intralesi, pembedahan, dan terapi fisik. Dewasa ini, injeksi kolagenase dari Clostridium histolyticum telah diklaim sebagai pengobatan alternatif non-bedah (Silva \& Skare, 2012).

Carpal tunnel syndrome (CTS) disebabkan oleh kompresi saraf median di bawah ligamentum karpal transversa. Sindrom ini ditandai dengan nyeri dan paresthesia di wilayah ibu jari ke bagian tengah jari keempat, yang memburuk pada malam hari dan dapat menjalar ke lengan bawah. Dalam kasus lebih lanjut, atrofi otot tenar dan kehilangan kekuatan cengkeraman dapat terjadi. Diagnosis klinis CTS ditegakkan dengan menggunakan manuver Phalen dan uji Tinel. Dalam kasus yang meragukan, studi elektrofisiologi dapat membantu. Dipercayai bahwa faktor predisposisi CTS yang sebenarnya adalah obesitas, yang umum pada pasien dengan DM tipe 2 (Silva \& Skare, 2012). Dalam sebuah studi terhadap 791 pasien dengan CTS yang dirujuk untuk studi elektrofisiologi,menunjukkan bahwa diagnosis DM, jenis kelamin perempuan, obesitas dan usia antara 41 dan 60 tahun merupakan faktor risiko CTS, namun, ketika data dikelompokkan menurut indeks massa tubuh pasien, hubungan dengan DM menghilang (Becker et al., 2002). Penatalaksanaan CTS berfokus pada analgesik dan bidai, sementara injeksi steroid topikal dan pembedahan dapat diindikasikan pada kasus yang lebih parah. Kemanjuran injeksi steroid topikal dewasa ini dikonfirmasi dalam tinjauan sistematis, tetapi masih dipertanyakan apakah pengurangan nyeri yang adekuat berlangsung lebih dari 1 bulan. Selain itu, pasien diabetes umumnya kurang responsif terhadap injeksi steroid dan mungkin memerlukan pembedahan (Papanas \& Maltezos, 2010). 
Trigger finger (juga disebut tenosinovitis fleksor) bermanifestasi sebagai fenomena jari yang terkunci saat fleksi, yang terutama mempengaruhi jari pertama, ketiga, dan keempat dan biasanya tidak menimbulkan rasa sakit, tetapi mungkin dapat menyakitkan. Pada penderita diabetes, hal ini dikaitkan dengan lama durasi diabetes, kontrol metabolisme yang buruk dalam jangka panjang, dan adanya komplikasi mikrovaskuler. Mekanisme yang mendasarinya antara lain hiperglikemia yang berlangsung lama, yang menyebabkan glikosilasi kolagen dan akumulasi kolagen di selubung tendon yang terkena. Dalam kasus ringan, manajemen melibatkan kontrol glikemik yang optimal dan fisioterapi. Dalam kasus refrakter, injeksi steroid topikal ke dalam selubung tendon yang terkena mungkin berguna, namun, pada tingkat kekambuhan yang tinggi, memerlukan pembedahan sebagai pengobatan definitif (Papanas \& Maltezos, 2010).

Gejala muskuloskeletal secara signifikan juga lebih umum dan parah pada wanita dengan DM tipe 2 dibandingkan pada wanita tanpa DM tipe 2 (Yang et al., 2019). Dalam penelitian Molsted et al (2012), melaporkan bahwa pasien dengan DM tipe 2 mengalami nyeri lebih sering di lengan, tangan, lutut, dan pinggul daripada pasien tanpa DM tipe 2 (Molsted et al., 2012). Selain itu, dalam sebuah penelitian yang dilakukan di Taiwan, kejadian kumulatif nyeri muskuloskeletal selama 10 tahun lebih tinggi pada kelompok diabetes dibandingkan nondiabetes (Pai et al., 2015). DM tipe 2 sering menyebabkan gejala muskuloskeletal yang umumnya terabaikan dan tidak diobati dengan baik dibandingkan dengan komplikasi kardiovaskular, paru, dan lainnya. Oleh karena itu, penyedia layanan kesehatan harus mewaspadai kemungkinan tanda dan gejala muskuloskeletal pada wanita paruh baya dengan DM tipe 2 untuk meningkatkan kualitas hidup mereka (Yang et al., 2019).

\section{Simpulan Dan Saran}

Prevalensi diabetes baik tipe 1 dan tipe 2 meningkat secara signifikan di seluruh dunia. Komplikasi vaskuler dari diabetes sudah diketahui dengan baik, yang merupakan penyebab utama mortalitas dan morbiditas dari kondisi tersebut. Sementara itu manifestasi muskuloskeletal dari diabetes juga sering ditemui dan meskipun tidak mengancam nyawa, merupakan penyebab penting dari morbiditas, nyeri dan kecacatan. Komplikasi muskuloskeletal yang sering dijumpai pada penderita diabetes melitus antara lain kapsulitis bahu, mobilitas sendi terbatas, kontraktur Dupuytren, carpal tunnel syndrome dan trigger finger. Kerusakan pembuluh dan saraf, glikosilasi protein, dan peningkatan kolagen di kulit dan jaringan ikat muskuloskeletal adalah beberapa faktor yang diduga berkontribusi dalam perkembangan gangguan muskuloskeletal pada penderita diabetes.

\section{Daftar Rujukan}

Arsanjani Shirazi, A., Nasiri, M., \& Yazdanpanah, L. (2016). Dermatological and musculoskeletal assessment of diabetic foot: A narrative review. Diabetes and Metabolic Syndrome: Clinical Research and Reviews, 10(2), S158-S164. https://doi.org/10.1016/j.dsx.2016.03.004

Becker, J., Nora, D. B., Gomes, I., Stringari, F. F., Seitensus, R., Panosso, J. S., \& Ehlers, J. A. C. (2002). An evaluation of gender, obesity, age and diabetes mellitus as risk factors for carpal tunnel syndrome. Clinical Neurophysiology, 113(9), 1429-1434. https://doi.org/10.1016/S1388-2457(02)00201-8

Boswell, S. B., Patel, D. B., White, E. A., Gottsegen, C. J., Forrester, D. M., Masih, S., \& Matcuk, G. R. (2014). Musculoskeletal manifestations of endocrine disorders. Clinical Imaging, 38(4), 384-396. https://doi.org/10.1016/j.clinimag.2014.02.014

Boyle, J. P., Thompson, T. J., Gregg, E. W., Barker, L. E., \& Williamson, D. F. (2010). 
Projection of the year 2050 burden of diabetes in the US adult population: Dynamic modeling of incidence, mortality, and prediabetes prevalence. Population Health Metrics, 8, 1-12. https://doi.org/10.1186/1478-7954-8-29

Kiani, J., Goharifar, H., Moghimbeigi, A., \& Azizkhani, H. (2014). Prevalence and risk factors of five most common upper extremity disorders in diabetics. Journal of Research in Health Sciences, 14(1), 93-96. https://doi.org/10.34172/jrhs141043

Lehuen, A., \& Ph, D. (2015). A Double-Edged Sword against Type 1 Diabetes. New England Journal of Medicine, 372(8), 778.

Merashli, M., Chowdhury, T. A., \& Jawad, A. S. M. (2015). Musculoskeletal manifestations of diabetes mellitus. Qjm, 108(11), 853-857. https://doi.org/10.1093/qjmed/hcv106

Molsted, S., Tribler, J., \& Snorgaard, O. (2012). Musculoskeletal pain in patients with type 2 diabetes. Diabetes Research and Clinical Practice, 96(2), 135-140. https://doi.org/10.1016/j.diabres.2011.12.022

Mooney, R. A., Sampson, E. R., Lerea, J., Rosier, R. N., \& Zuscik, M. J. (2011). High-fat diet accelerates progression of osteoarthritis after meniscal/ligamentous injury. Arthritis Research and Therapy, 13(6). https://doi.org/10.1186/ar3529

Moseley, K. F. (2012). Type 2 diabetes and bone fractures. Current Opinion in Endocrinology, Diabetes and Obesity, 19(2), 128-135. https://doi.org/10.1097/MED.0b013e328350a6e1

Mustafa, K. N., Khader, Y. S., Bsoul, A. K., \& Ajlouni, K. (2016). Musculoskeletal disorders of the hand in type 2 diabetes mellitus: prevalence and its associated factors. International Journal of Rheumatic Diseases, 19(7), 730-735. https://doi.org/10.1111/1756-185X.12617

Nichols, A. E. C., Oh, I., \& Loiselle, A. E. (2020). Effects of Type II Diabetes Mellitus on Tendon Homeostasis and Healing. Journal of Orthopaedic Research, 38(1), 13-22. https://doi.org/10.1002/jor.24388

Pai, L. W., Hung, C. T., Li, S. F., Chen, L. L., Chung, Y. C., \& Liu, H. L. (2015). Musculoskeletal pain in people with and without type 2 diabetes in Taiwan: A population-based, retrospective cohort study. BMC Musculoskeletal Disorders, 16(1), 1-7. https://doi.org/10.1186/s12891-015-0819-4

Papanas, N., \& Maltezos, E. (2010). The diabetic hand: a forgotten complication? Journal of Diabetes and Its Complications, 24(3), 154-162. https://doi.org/10.1016/j.jdiacomp.2008.12.009

Ramchurn, N., Mashamba, C., Leitch, E., Arutchelvam, V., Narayanan, K., Weaver, J., Hamilton, J., Heycock, C., Saravanan, V., \& Kelly, C. (2009). Upper limb musculoskeletal abnormalities and poor metabolic control in diabetes. European Journal of Internal Medicine, 20(7), 718-721. https://doi.org/10.1016/j.ejim.2009.08.001

Saputri, R. D. (2020). Jurnal Ilmiah Kesehatan Sandi Husada ARTIKEL PENELITIAN Komplikasi Sistemik Pada Pasien Diabetes Melitus Tipe 2 Pendahuluan. 11(1), 230236. https://doi.org/10.35816/jiskh.v10i2.254

Schett, G., Kleyer, A., Perricone, C., Sahinbegovic, E., Iagnocco, A., Zwerina, J., Lorenzini, R., Aschenbrenner, F., Berenbaum, F., D’Agostino, M. A., Willeit, J., \& Kiechl, S. (2013). Diabetes is an independent predictor for severe osteoarthritis: Results from a longitudinal cohort study. Diabetes Care, 36(2), 403-409. https://doi.org/10.2337/dc12-0924

Silva, M. B. G., \& Skare, T. L. (2012). Musculoskeletal disorders in diabetes mellitus. Revista Brasileira de Reumatologia, 52(4), 601-605. https://doi.org/10.1590/S048250042012000400010

Singla, R., Gupta, Y., \& Kalra, S. (2015). RECENT ADVANCES IN ENDOCRINOLOGY Musculoskeletal effects of diabetes mellitus. JPMA. The Journal of the Pakistan 
Medical Association, 65(9), 1024-1027. \%5Cn\%5Cn1.\%5CnJPMA. The Journal of the Pakistan Medical Association1.\%5CnJPMA. The Journal of the Pakistan Medical Association

Uhl, R. L., Rosenbaum, A. J., DiPreta, J. A., Desemone, J., \& Mulligan, M. (2014). Diabetes mellitus: Musculoskeletal manifestations and perioperative considerations for the orthopaedic surgeon. Journal of the American Academy of Orthopaedic Surgeons, 22(3), 183-192. https://doi.org/10.5435/JAAOS-22-03-183

Varma, A. K. (2013). Charcot Neuroarthropathy of the Foot and Ankle: A Review. Journal of Foot and Ankle Surgery, 52(6), 740-749. https://doi.org/10.1053/j.jfas.2013.07.001

Yang, Y. L., Chee, W., \& Im, E. O. (2019). Type 2 Diabetes and Musculoskeletal Symptoms Among Midlife Women. Diabetes Educator, 45(5), 520-528.

https://doi.org/10.1177/0145721719872558 